\title{
Memories in context: the social and economic function of cinema in 1950s Rome
}

Daniela Treveri Gennari (Oxford Brookes University) and John Sedgwick (University of Portsmouth, University of Utrecht)

Daniela Treveri Gennari is Reader in Film Studies at Oxford Brookes University, UK. Her research on Catholic cinema in Italy was published in the volume Post-war Italian Cinema: American Intervention, Vatican Interests (Routledge, 2009). Her work on Italian cinema, censorship and Catholicism also appeared in readers such as Italy on Screen (Peter Lang), Silencing Cinema (Palgrave) and journals such as October and New Review of Film and Television Studies. After a pilot project on audiences and memories of cinema-going in postwar Rome, as part of a successful British Academy Mid Career Fellowship, she is now leading a major AHRC funded project on Audiences in 1950s Italy.

John Sedgwick is a Professor in the Business School of the University of Portsmouth, and Associate Researcher in the Research Institute for History and Culture (OGC) at the University of Utrecht. He researches into the business and economic history of cinema and has published articles in various business, economic and film history journals. He has also published a monograph Filmgoing in Britain during the 1930s: a choice of pleasure (Exeter University Press). 


\title{
Memories in context: the social and economic function of cinema in 1950s Rome
}

\begin{abstract}
During the 1950s cinema in Italy blossomed, bringing Italians film entertainment on an unprecedented scale. This study draws upon the testimonies of 325 elderly Romans about their filmgoing experiences during this period. These memories are set in the particular context of the film programmes that they (and fellow filmgoers) choose between information that is derived from daily newspapers and supplemented with trade listings of the most popular films screened in Rome. In producing a bottom-up account of filmgoing, the paper contributes to the general debate about film culture in Italy in the post-war era.
\end{abstract}

During the 1950s cinema in Italy blossomed bringing Italians film entertainment on an unprecedented scale, while capturing approximately 70 per cent of all entertainment revenues. ${ }^{1}$ One authority has it that there was one cinema seat for every nine inhabitants more than in Great Britain (1:12) and France (1:16). ${ }^{2}$ Browning and Sorrell (1954), produce figures to indicate in 1950 on average Italians made 14 visits annually to the cinema - ahead of both France (9), and West Germany (11). ${ }^{3}$ By 1955 this figure had risen to 17 visits per head (see Table 1).

The post-war 'Americanization' of Italy/Western Europe, in which films played such an important role, has been well documented. ${ }^{4}$ Certainly Hollywood films were integral to sating the public's appetite for cinema, taking a leading share of the market. Particularly attractive to Italian audiences were big budget Technicolor productions that had epic and historical dimensions. But, at the same time, audiences were also attracted to films made on much more modest budgets by indigenous producers that spoke to them in the vernacular of their own language and were filmed in black and white ${ }^{5}$. Between them, Hollywood and Italian films dominated the market. However, the provision of film entertainment and the economic imperatives of the various agencies involved is only part of the story. The other part is the social aspect: the cinema as a venue where people met and shared experience, including of 
course the film featured on the programme. As will become apparent in the paper, it is this social function that remains strongest in people's memories, irrespective of the degree of comfort and luxury associated with the venues they attended. One imagines that the social significance of going to the cinema was very much more marked at that time when compared with today.

In her study of the economics of the post-war Italian cinema, Barbara Corsi argues that by the end of the 1950s - after a decade of sustained economic growth - audiences in Italy begin to diversify, moving away from the state of 'homogeneous spectatorship' that she believed characterised the immediate post-war years. ${ }^{6}$ They did this by developing distinctive preferences in terms of both film and cinema theatre choices. Is this view of Italian cinemagoers consistent with the evidence? Using the oral histories of elderly Romans, now in their late 70s or early 80 s, this research investigates the films they saw and the cinemas they saw them in during their active years of cinemagoing in the 1950s. ${ }^{7}$

In setting audience memories in context, the article thus adopts a multiple methods form of investigation, in which audiences are studied both from an experiential and numerical standpoint. ${ }^{8}$ Our findings provide a corrective to Corsi's depiction of the evolution of the character of Italian cinemagoers by revealing a fully developed exhibition sector in operation in Rome earlier than suggested by her, in which first, second and third-run cinemas were carefully differentiated. ${ }^{9}$ The oral evidence produced in the article suggests that each cinema run performed a distinctive role in the diffusion of movies, attracting different types of audience, and yielding a different type of experience: a market that was at the same extensive, delineated between the centre and the periphery, and deep -termed by a contemporary commentator a 'mercato di profondità'. ${ }^{10}$ 
Combining an account of how this 'system of provision' worked in Rome in the 1950s with the oral evidence presented by our survey participants is the main task of this paper. In developing this bottom-up approach to film audience research, the intention is to provide a more thorough understanding of audience behaviour and experience. This article continues in four parts. The next part describes the sources of data and methods used, followed by an analysis of context that changes in scope from a macro to a micro account of film consumption and exhibition. A third section reports the oral histories provided by the sample of elderly Romans questioned and interviewed in the study. A discussion then follows in which a number of concluding remarks are made.

\section{The two methods and sources of data}

Annette Kuhn (2002) has argued that '...going to the pictures was the occasion for the earliest ventures into the world beyond the home. Close to home, almost an extension of home, and yet not home, 'the picture' is remembered as both daring and safe'. ${ }^{11}$ For Kuhn there is a geography, anthropology and sociology associated with cinemagoing. From an economics perspective, Douglass North (1990) refers to these types of factor as informal institutional arrangements, which differ from place to place, territory to territory, giving form to idiosyncratic practice and experience. ${ }^{12}$

However, while idiosyncrasy is ever present in the particular, an underlying economic logic prevails: a logic that indeed pervades the history of the movie industry. Made possible by countless coordinating decisions, the movie business is predicated on the principle of revenue maximisation: that faced with a set of fixed (sunk) costs financiers, producers, distributors and exhibitors are motivated by squeezing as much revenue as they possibly can from the films with which they are connected. A necessary condition for this to happen is that 
distribution and exhibition are sufficiently flexible to respond to audience demand for particular films once revealed, making popular films more readily available than less popular films. In organising around this principle, the Italian industry during the post-war period was no different from any other centre of movie production, distribution, exhibition and consumption in the developed capitalist world.

At the apex of the revenue maximizing process is the feature film, supported by a programme of screen and non-screen items that serve jointly the purpose of elongating the entertainment consumed by audiences. Put differently, it is not the newsreel, the cartoon, the trailer, or the second feature on a double bill programme that draws audiences to the particular cinema on a particular day. If it were, then box-office revenues would be invariant between programmes screened at the same cinema, featuring different top-of-the-bill films. This is not the case. ${ }^{13}$ Thus, screened at a cinema and seen by a paying audience, the feature film constitutes a geographical and temporal point at which industry supply arrangements interface with the lives and preferences of film audiences. It can be understood as a confluence where financial, production, exhibition, and consumption decisions come together, in effect constituting an imprint (the DNA) of the business as a whole. In conjunction with box-office data, the feature film serves as a unit of analysis, which when aggregated allows assessments to be made about the relative popularity of films and audience preferences. Of course, this aggregation can be applied to a locality, province, or territory, or, indeed, used to make comparisons between any of these. ${ }^{14}$

Oral evidence was gleaned from a survey of 325 people who lived in Rome between the years 1945-1960. Interviews were held between September and December 2012, when 325 people aged 65-90 filled in a questionnaire (labelled LAR001 to LAR325) comprising a range of quantitative and qualitative questions. ${ }^{15}$ The recruitment process entailed selecting participants who attended centres for the elderly in the capital, as well as GP practices, holiday resorts, and residential homes. Demographic information collected included age, education level, family composition, religious and political beliefs, leisure activities as well 
as details of residency and socio-economic status. Cinema-going decisions were investigated through questions covering ticket prices, factors determining the selection of films, as well as preferences of days and types of cinemas. In an open ended section participants were also asked to write about their memories of cinema-going, aided by prompts about favourite theatres, stars, and films, as well as broader matters such as what cinema represented for them, and those factors that influenced their decisions to attend particular cinemas and watch particular films. When participants in the survey were asked to identify one or more films which had made a strong impression on them, 177 named films that were released in Rome during the 12 years following the end of the Second World War, most of whom (108) remember seeing these films during the seven years, 1950 to 1956; the period that has become the focus of this study. The interviews were supplemented by 32 video diaries available on-line at <http://italiancinemaaudiences.org/>, the purpose of which was to get respondents to expand upon a number of issues that arose from the questionnaires.

The source of film programme information is the daily listings found on page 6 of the Roman edition of the Communist Party daily newspaper l'Unità, the archive of which is on-line, backed up by the daily listings found in the evening paper Momento Sera, and the daily Il Tempo. ${ }^{16}$ From this information a dataset was created comprising the daily programmes of 130 Roman cinemas for the 28 days, 2-29 January $1954 .{ }^{17}$ This dataset provides an insight into how the market worked: of how films filtered out from first-run to second and third-run cinemas. Given the assumption that films that were popular were screened more frequently than films that were not, the programme data captures implicitly the film choices audiences made and, hence, what their preferences were. In conjunction with the memories of the survey participants, it is possible to come to an understanding of how the cinemas in these different runs served audiences, differentiated by locality, gender and/or social class. The 
evidence also helps to identify patterns of audience behaviour as well as the characteristics of film performance. The fact that first-run cinemas frequently held films over from one week to the next, while some third-run cinemas rarely held them over for more than a day, indicates that at any one time a distinction existed between films that served as attractions of the day and films that served as programmers, even though some of the latter, on release, had earlier been main attractions. ${ }^{18}$ Indeed, such was the depth of the diffusion process, that one contemporary maintained that some 70 per cent of film revenues came from non-first-run cinemas. ${ }^{19}$

To put both testimonial evidence and film programme knowledge into context, data is drawn from two principal sources: SIAE (the Italian Society of Authors and Publishers) - a multipurpose society which administers copyright related to all kinds of intellectual works published detailed annual statistics of cinemagoing in Italy in its organ Annuario dello Spettacolo, while the exhibitors' organisation AGIS produced a bi-weekly publication Bollettino dello Spettacolo listing (not always consistently) the aggregate box-office grosses derived from (mostly) first-run (prima visione) category cinemas in the largest Italian cities. 
Table 1. Assorted cinema statistics

\begin{tabular}{|c|c|c|c|c|c|c|c|c|c|c|}
\hline Year & $\begin{array}{l}\text { Consumer } \\
\text { Price Deflator } \\
(1950=1) \\
(1)\end{array}$ & $\begin{array}{c}\text { Films }^{2} \\
\text { (2) }\end{array}$ & $\begin{array}{l}\text { Cinema box- } \\
\text { office }^{3} \text { (lire in } \\
\text { millions at } \\
1950 \text { prices) } \\
\text { (3) }\end{array}$ & $\begin{array}{l}\text { Box-office } \\
\text { as a } \\
\text { proportion } \\
\text { of all paid- } \\
\text { for leisure } \\
\text { (4) }\end{array}$ & $\begin{array}{c}\text { Ticket sales } \\
\text { (millions) } \\
(5)_{-}\end{array}$ & $\begin{array}{c}\text { Mean } \\
\text { admission }^{5} \text { (in lire } \\
\text { prices } \\
\text { at } 1950 \text { prices) } \\
\text { (6) }\end{array}$ & $\begin{array}{c}\text { Operating } \\
\text { cinemas } \\
\text { (7) }\end{array}$ & $\begin{array}{c}\text { Popularion } \\
\text { per cinema } \\
\\
\left(8^{7}\right.\end{array}$ & $\begin{array}{c}\text { Admissions } \\
\text { per capita } \\
\text { (9) }\end{array}$ & $\begin{array}{l}\text { Box-office per } \\
\text { cinema }^{7} \text { (lire } \\
\text { in } 1950 \\
\text { prices) } \\
(10)\end{array}$ \\
\hline 1945 & 0.49 & 45 & 13,173 & 0.73 & & & & & & \\
\hline 1946 & 0.58 & 209 & 23,923 & 0.72 & 417 & 57.4 & & & & \\
\hline 1947 & 0.94 & 361 & 30,818 & 0.70 & 532 & 57.9 & & & & \\
\hline 1948 & 1.00 & 361 & 42,747 & 0.67 & 588 & 72.7 & & & & \\
\hline 1949 & 1.01 & 491 & 53,519 & 0.69 & 616 & 86.9 & & & & \\
\hline 1950 & 1.00 & 407 & 63,404 & 0.69 & 662 & 95.8 & & & & \\
\hline 1951 & 1.10 & 486 & 66,723 & 0.70 & 706 & 94.6 & 8,678 & & & $7,452,535$ \\
\hline 1952 & 1.14 & 512 & 73,156 & 0.70 & 748 & 97.8 & 8,953 & 5,253 & 15.9 & $7,652,348$ \\
\hline 1953 & 1.17 & 489 & 81,047 & 0.71 & 778 & 104.2 & 9,560 & 4,922 & 16.5 & $8,148,698$ \\
\hline 1954 & 1.20 & 502 & 87,837 & 0.71 & 801 & 109.7 & 9,946 & 4,752 & 16.9 & $8,309,990$ \\
\hline 1955 & 1.23 & 512 & 94,795 & 0.69 & 819 & 115.7 & 10,570 & 4,565 & 17.0 & $8,918,570$ \\
\hline 1956 & 1.29 & 383 & 89,784 & 0.68 & 790 & 113.6 & 10,629 & 4,578 & 16.2 & $8,511,945$ \\
\hline
\end{tabular}

Sources and Notes: (1) Sommario di statistiche storiche 1861-2010, Table 21.5, Istat. The index series represents the prices experienced by the households of workers and other employees; (2-7) Annuario dello Spettacolo 1957, SIAE: (2), Table 56; (3), Table 1; (4), Table 26; (5), Table 26; (6), Table 43; (7), Table 38. 


\section{The cinema context}

By 1950 the film industry had taken a dominant position as a source of entertainment in the lives of the Italian people. As Table 1 (column 4) shows, cinema captured approximately 70 per cent of entertainment revenues during these years in what was a rapidly growing market: a combination of rising attendances and real admission prices led to a near four-fold growth in the box-office (measured in 1950 prices) between 1946 and 1955. Indeed, cinema attendance peaked in 1955, some 10 years later than in Great Britain and the United States, although as Miskell and Nicoli show, inflation adjusted revenues continued to hold up during the next fifteen years, even though attendances fell back, a consequence of rising admission prices. ${ }^{20}$ Italy was extremely well endowed with cinemas in the $1950 \mathrm{~s}$, with a very low ratio of population to cinemas when contrasted with other comparable national markets. This is even more the case when the Catholic provision of cinematic entertainment ('Parish Cinema') is taken into account. ${ }^{21}$ By 1950 , there was no shortage of cinemas, or, for that matter, films for Italians to choose between.

Table 2 shows that between 1950 and 1956 Italians largely went to see Hollywood or Italian films; a situation similar to that that prevailed before the formation of the Ente Nationale Industria Cinematografia (ENIC) in 1939 - a measure which took film distribution into State control, effectively causing the Americans to leave the market. ${ }^{22}$ The volume of Italian output listed in Table 2 suggests a developed industrial capacity to make films. This, coupled with the fact that for the first five years of the series Italian films generated a higher mean boxoffice than their Hollywood counterparts, suggests an environment in which the genres, stars and directors of post-war Italian cinema flourished. The dramatic decline in the fortune of Italian films shown in Table 2 in 1955 and 1956 was the direct consequence of the much better performance in the market on the part of Hollywood's top films, part of which was connected to the growing presence in the portfolios of the Major studios of high budget epic films presented in Cinemascope format. ${ }^{23}$ 
Table 2. Relative shares of Italian and Hollywood made films in the Italian market, 1950 to 1956

\begin{tabular}{|c|c|c|c|c|c|c|c|c|c|c|}
\hline \multirow[b]{2}{*}{$\begin{array}{c}\text { Year of box- } \\
\text { office }\end{array}$} & \multicolumn{5}{|c|}{ Italian films } & \multicolumn{5}{|c|}{ Hollywood Films } \\
\hline & $\begin{array}{l}\text { Number of } \\
\text { Italian Films }\end{array}$ & $\begin{array}{l}\text { Percentage } \\
\text { of total } \\
\text { films }\end{array}$ & $\begin{array}{l}\text { Box-office (Lire } \\
\text { in millions } \\
\text { in1950 prices) }\end{array}$ & $\begin{array}{c}\text { Percentage } \\
\text { of total }\end{array}$ & $\begin{array}{l}\text { Mean Box- } \\
\text { office (Lire } \\
\text { in millions } \\
\text { in1950 } \\
\text { prices) }\end{array}$ & $\begin{array}{c}\text { Number of } \\
\text { Hollywood } \\
\text { Films }\end{array}$ & $\begin{array}{l}\text { Percentage } \\
\text { of total } \\
\text { films }\end{array}$ & $\begin{array}{l}\text { Box-office (Lire } \\
\text { in millions } \\
\text { in1950 prices) }\end{array}$ & $\begin{array}{c}\text { Percentage } \\
\text { of total }\end{array}$ & $\begin{array}{l}\text { Mean Box- } \\
\text { office (Lire } \\
\text { in millions } \\
\text { in1950 } \\
\text { prices) }\end{array}$ \\
\hline 1950 & 92 & 19.8 & 6,459 & 29.2 & 70 & 277 & 59.6 & 14,086 & 63.7 & 51 \\
\hline 1951 & 104 & 21.4 & 7,014 & 30.1 & 67 & 268 & 55.1 & 14,706 & 63.0 & 55 \\
\hline 1952 & 132 & 27.2 & 9,217 & 36.8 & 70 & 258 & 53.1 & 14,197 & 56.7 & 55 \\
\hline 1953 & 146 & 25.5 & 11,417 & 38.2 & 78 & 287 & 50.2 & 16,187 & 54.1 & 56 \\
\hline 1954 & 190 & 29.0 & 12,257 & 39.0 & 65 & 314 & 48.1 & 16,764 & 53.3 & 53 \\
\hline 1955 & 126 & 28.5 & 7,270 & 23.1 & 58 & 232 & 52.5 & 21,778 & 69.2 & 94 \\
\hline 1956 & 91 & 23.8 & 4,888 & 19.7 & 54 & 184 & 48.0 & 16,626 & 66.9 & 90 \\
\hline
\end{tabular}

Source: Annuario dello Spettacolo.

Note: For 1950, edition 1951, Table 47; for 1951, edition 1952, Table 47; for 1952, edition 1953, Table 53; for 1953, edition 1954, Table 50; for 1954, edition 1955, Table 46, for 1955, edition 1956, Table 48; and for 1956, edition 1957, Table 55 
In keeping with division of the country between an industrial and prosperous North and agricultural and underdeveloped South, the statistics presented in Table 3 confirm a NorthSouth divide in cinemagoing practice. In the words of a contemporary commentator, '... $\mathrm{a}$ higher concentration of more expensive cinemas can be found in the North of the country, which diminishes in the Centre and reaches its lowest in the South - evidence of the regional variation in income per inhabitant'.${ }^{24}$ However, one must be careful not to overdo this difference. Table 3 shows that while per capita expenditure on tickets indicate that cinemagoers in the southern cities spent significantly less annually than their northern compatriots, they also paid lower admission prices. Furthermore, statistics presented in the Annuario dello Spettacolo show that between 1952 and 1957 the growth in the number of cinemas was greater in the South than in the North, reducing the number of inhabitants per cinema in the three poorest provinces of Basilicata, Calabria and Sicily from 9,585, 9,921, and 9,604 to $7,097,7,851$ and 6,697 respectively, compared to the national average of 5,253 in 1951 and 4,663 in $1957 .{ }^{25}$ Thus, it would appear that filmgoing was an important social activity for all urban Italians, irrespective of where they lived. What-is-more, the films that Italians were watching were by and large of recent vintage, with less than 10 per cent of 1956 box-office revenue generated by films released in 1952 and before - an indicator that distributors followed the business practice of removing systematically from circulation films that had had wide circulation through the various runs, in order to make room for films recently released. ${ }^{26}$

From Table 3 it is evident that Rome, with 250 permanent cinemas, was the largest urban market for films in Italy, boasting significantly more cinemas, ticket sales and screening days than Milan. ${ }^{27}$ Also, on average Romans went to the cinema more often than other Italian city populations - 35 times during 1956, compared to 33 in Bologna, Milan and Genoa. The city 
was also the centre of the Italian film industry; home to production studios, film crews, distribution companies, and the multifarious services linked to cinema such as casting, costume design, and dubbing. Not surprisingly, industry organisations such as ANICA (Associazione Nazionale Industrie Cinematografiche e Affini) and AGIS (Associazione Generale Italiana dello Spettacolo) - respectively the national associations of producers, and distributors and exhibitors - along with the editorial offices of the main film journals were also located in Rome. ${ }^{28}$

Table 3: Cinemagoing statistics for Italy's major provincial cities in 1956

\begin{tabular}{|c|c|c|c|c|c|c|c|c|}
\hline Cities & $\begin{array}{l}\text { Population } \\
\text { (1) }\end{array}$ & $\begin{array}{c}\text { Cinemas } \\
\text { (2) }\end{array}$ & $\begin{array}{c}\text { Screening } \\
\text { days } \\
(3)\end{array}$ & $\begin{array}{c}\text { Tickets sales } \\
\text { (4) }\end{array}$ & $\begin{array}{l}\text { Tickets per } \\
\text { capita } \\
(5)\end{array}$ & $\begin{array}{c}\text { Box-office } \\
\text { expenditure (lire) } \\
(6)\end{array}$ & $\begin{array}{c}\text { Mean } \\
\text { admission } \\
\text { prices (lire) } \\
(7)\end{array}$ & $\begin{array}{c}\text { Ticket } \\
\text { expenditure } \\
\text { per capita } \\
\text { (8) }\end{array}$ \\
\hline Roma & $1,787,997$ & 250 & 75,179 & $63,243,080$ & 35 & $11,515,056,545$ & 182 & 6,440 \\
\hline Milano & $1,328,372$ & 215 & 56,454 & $43,640,870$ & 33 & $9,821,585,262$ & 225 & 7,394 \\
\hline Napoli & $1,078,071$ & 127 & 41,229 & $25,292,300$ & 23 & $4,176,984,487$ & 165 & 3,875 \\
\hline Torino & 821,146 & 145 & 37,149 & $23,641,910$ & 29 & $5,142,015,207$ & 218 & 6,262 \\
\hline Genova & 719,205 & 121 & 35,080 & $23,872,930$ & 33 & $4,360,753,601$ & 183 & 6,063 \\
\hline Palermo & 541,890 & 66 & 24,419 & $14,036,270$ & 26 & $2,212,374,130$ & 158 & 4,083 \\
\hline Firenze & 483,761 & 75 & 23,390 & $15,721,730$ & 32 & $2,869,334,450$ & 183 & 5,931 \\
\hline Bologna & 398,104 & 77 & 18,285 & $13,270,400$ & 33 & $2,593,808,002$ & 196 & 6,515 \\
\hline Venezia & 374,087 & 73 & 17,496 & $8,656,590$ & 23 & $1,621,517,117$ & 187 & 4,335 \\
\hline Catania & 330,652 & 43 & 16,510 & $9,348,730$ & 28 & $1,508,415,835$ & 161 & 4,562 \\
\hline Bari & 329,241 & 32 & 10,268 & $8,452,740$ & 26 & $1,194,479,240$ & 141 & 3,628 \\
\hline Trieste & 293,744 & 55 & 17,235 & $8,572,080$ & 29 & $1,482,299,502$ & 173 & 5,046 \\
\hline Messina & 280,781 & 43 & 10,140 & $5,748,180$ & 20 & $889,271,824$ & 155 & 3,167 \\
\hline
\end{tabular}

Source: Annuario dello Spettacolo, Tables 30, 39.

Cinemas in the major cities of Italy were divided into three tiers - termed prima, seconda and terza visione (first, second and third run) - an economic arrangement that was formalised through the licencing arrangements of local authorities. ${ }^{29}$ In this mode of operation, films were distributed out in time and space from box-office rich (high price) cinemas located (usually) in city centres through various demarcated tiers of cinemas that charged lower admission prices and were generally less well accoutred.

Annuario dello Spettacolo produced a number of tables detailing the distribution of ticket 
prices. In Italy in 1956 the mean cinema price was Lire $147 .{ }^{30}$ Other than in Messina, Table 3 shows the mean price of cinema admission in the largest Italian cities to have been more than this, in some cities markedly so. Table 4 reproduces ticket aggregate price information for these 28 cities (all with populations greater than 200,000) and for the Italian market as a whole, confirming that city dwellers paid more on average to go to the cinema: just below 60 per cent of all Italy audiences paid Lire 150 or less for admission, while 61 per cent of inhabitants living in the big cities paid more. From Table 4 it is clear that film prices varied considerably, with prices above Lire 450 the exclusive preserve of a tiny number of exclusive city cinemas. However, at the other end of the spectrum, it is interesting to note that in both the city and all Italy categories, most Italian cinemagoers paid in the range of Lire 101 to 150.

Table 4. The distribution of cinema tickets sold at various prices in 1956

\begin{tabular}{|c|c|c|c|c|c|}
\hline Lire & $\begin{array}{c}\text { Tickets sold in } \\
\text { the cities }{ }^{1} \\
\text { (1) }\end{array}$ & $\begin{array}{l}\text { Tickets sold } \\
\text { throughout Italy } \\
\text { (2) }\end{array}$ & $\begin{array}{c}\operatorname{col} 1 / \operatorname{col} 2 \\
(3)\end{array}$ & $\begin{array}{c}\text { Cumulative } \\
\text { Proportion of } \\
\text { city } \\
\text { audiences in } \\
\text { each price } \\
\text { class }\end{array}$ & $\begin{array}{l}\text { Cumulative } \\
\text { Proprtion of } \\
\text { Italian } \\
\text { audiences in } \\
\text { each price } \\
\text { class }\end{array}$ \\
\hline Up to 50 & 150,820 & 853,190 & 0.18 & 0.01 & 0.01 \\
\hline 51 to 100 & $2,148,480$ & $17,797,870$ & 0.12 & 0.10 & 0.27 \\
\hline 101 to 150 & $7,444,730$ & $21,993,790$ & 0.34 & 0.41 & 0.59 \\
\hline 151 to 200 & $5,678,770$ & $13,065,850$ & 0.43 & 0.65 & 0.79 \\
\hline 201 to 250 & $3,396,820$ & $7,584,190$ & 0.45 & 0.80 & 0.90 \\
\hline 251 to 300 & $1,544,090$ & $3,197,560$ & 0.48 & 0.86 & 0.94 \\
\hline 301 to 350 & $1,122,250$ & $1,660,310$ & 0.68 & 0.91 & 0.97 \\
\hline 351 to 400 & 621,110 & 627,310 & 0.99 & 0.93 & 0.98 \\
\hline 401 to 450 & 668,830 & 679,980 & 0.98 & 0.96 & 0.99 \\
\hline 451 to 500 & 261,170 & 261,170 & 1.00 & 0.97 & 0.99 \\
\hline 501 to 550 & 209,140 & 209,140 & 1.00 & 0.98 & 0.99 \\
\hline 551 to 600 & 179,870 & 179,870 & 1.00 & 0.99 & 1.00 \\
\hline Over 600 & 220,180 & 220,180 & 1.00 & 1.00 & 1.00 \\
\hline Total & $23,646,260$ & $68,330,410$ & & & \\
\hline
\end{tabular}

Source: Annuario dello Spettacolo, Table 53

Note: ${ }^{1}$ Cities with populations of over 200,000 
We would expect first-run cinemas in Rome to be expensive in relation to other cinemas in Rome and, as shown in Table 5, such expectations are not disappointed. Secondary evidence for this comes from the daily evening paper Momento Sera, which listed admission price ranges as well as location details and daily screening times. In Rome prices varied at the top end from Lire 800 to 1000 charged by the cinema Barberini, to the Lire 60 to 70 , and 60 to 80 price range set respectively by the managements of the Lux, and Centrale. In keeping with the model of how films were distributed through the various tiered sub-markets, ticket prices show a strong negative correlation (-0.8) with the number of programmes screened by cinemas on average each week - high prices, low turnover and low prices, high turnover.

Table 5 presents a film programming profile of the cinemas of Rome, based upon the film programmes of 130 cinemas listed daily in the Roman edition of the communist newspaper l'Unità. These were collected for the 28 screening days, from 2 to 29 January 1954. Of these cinemas, 114 had either complete records (or were missing one day) and are those named in Table 5. Between them they ran 1,539 film programmes screening over 800 distinct features during the four weeks, always it would seem on single bill programmes. ${ }^{31}$ From Table 5, it is apparent that different cinemas perform different roles. At the extremes, the very expensive Barberini and Capitol cinemas screened one film apiece for the duration: respectively Pane, amore e fantasia (1953) and La Tunica (The Robe, 1953), while three cinemas the Palazzo, Corallo, and ABC screened 26 films, more-or-less a separate film for every day of the week. The cinemas listed as having 'Up to 1 change' and ' 1 to 2 changes' per week correspond with those listed as first-run (prima visione) cinemas in the newspapers Il Tempo and Momento Sera. The frequency distribution of film turnover is shown in Figure 1. The velocity of film circulation is indeed astonishingly high, requiring a highly effective industrial organisation to schedule and then get the films to the cinemas. ${ }^{32}$ Of the 114 cinemas listed in Table 5, 75 screened three or more films a week. 
Table 5. Roman cinemas, their prices and the number of weekly change programmes, 2 -28 January 1954

\begin{tabular}{|c|c|c|c|c|c|c|c|c|}
\hline Cinemas & $\begin{array}{l}\text { Mid-range } \\
\text { Price (Lire) }\end{array}$ & $\begin{array}{l}\text { No. of films } \\
\text { screened }\end{array}$ & Cinemas & $\begin{array}{l}\text { Mid-range } \\
\text { Price (Lire) }\end{array}$ & $\begin{array}{l}\text { No. of films } \\
\text { screened }\end{array}$ & Cinemas & $\begin{array}{l}\text { Mid-range } \\
\text { Price (Lire) }\end{array}$ & $\begin{array}{l}\text { No. of films } \\
\text { screened }\end{array}$ \\
\hline \multicolumn{3}{|c|}{ Up to 1 change per week } & \multicolumn{3}{|c|}{3 to 4 changes per week } & \multicolumn{3}{|c|}{4 to 5 changes per week } \\
\hline Barberini & 900 & 1 & Appio & 200 & 13 & Del Vascello & 185 & 17 \\
\hline Capitol & 500 & 1 & Eden & 175 & 13 & Aureo & 100 & 17 \\
\hline Ariston & 500 & 2 & Induno & 155 & 13 & Centrale & 70 & 17 \\
\hline Fiamma & $\mathrm{n} / 1$ & 2 & Castello & 150 & 13 & Cinestar & 165 & 17 \\
\hline Attualita & 300 & 3 & Clodio & $\mathrm{n} / \mathrm{l}$ & 13 & Cristallo & 100 & 17 \\
\hline Capranichetta & 350 & 3 & Iris & 110 & 13 & Doria & $\mathrm{n} / \mathrm{l}$ & 17 \\
\hline Corso & 550 & 3 & Ottaviano & 120 & 13 & Roma & 100 & 17 \\
\hline Imperiale & 400 & 3 & Rialto & 165 & 13 & Stadium & 140 & 17 \\
\hline Metropolitan & 450 & 3 & Volturno & 180 & 13 & Tirreno & 120 & 17 \\
\hline Moderno & 500 & 3 & Alcyone & $\mathrm{n} / 1$ & 13 & Lux & 65 & 17 \\
\hline Moderno Sale & 400 & 3 & Arenula & 80 & 13 & Plinius & 120 & 18 \\
\hline Quirinetta & 350 & 3 & Giulio Cesare & $\mathrm{n} / \mathrm{l}$ & 13 & Rubino & 103 & 18 \\
\hline Rivoli & $\mathrm{n} / 1$ & 3 & XXI Aprile & $\mathrm{n} / 1$ & 13 & Silver cine & $\mathrm{n} / \mathrm{l}$ & 18 \\
\hline Plaza & 300 & 4 & Alhambra & 215 & 13 & Verbano & 145 & 18 \\
\hline \multicolumn{3}{|c|}{1 to 2 changes per week } & Manzoni & 130 & 14 & Platino & $\mathrm{n} / \mathrm{l}$ & 19 \\
\hline Bernini & 255 & 5 & Nuovo & 155 & 14 & Delle Terrazzє & 120 & 19 \\
\hline Adriano & 375 & 5 & Quirinale & 255 & 14 & Diana & 150 & 19 \\
\hline Arcobaleno & 600 & 5 & $\operatorname{Rex}$ & 160 & 14 & Orfeo & 120 & 19 \\
\hline Galleria & 425 & 5 & Acquario & $\mathrm{n} / \mathrm{l}$ & 14 & Colosseo & $\mathrm{n} / \mathrm{l}$ & 20 \\
\hline Supercinema & 475 & 5 & Augustus & 150 & 14 & Italia & 185 & 20 \\
\hline Salone Margh & 350 & 5 & Mazzini & 140 & 14 & Massimo & 140 & 20 \\
\hline Capranica & 450 & 7 & Ambra Jovine & $\mathrm{n} / 1$ & 14 & \multicolumn{3}{|c|}{5 to 6 changes per week } \\
\hline Europa & 475 & 7 & Flaminio & 100 & 14 & Apollo & 130 & 21 \\
\hline Trevi & 275 & 7 & Alba & 110 & 15 & Ionio & $\mathrm{n} / \mathrm{l}$ & 21 \\
\hline Fiammetta & $\mathrm{n} / \mathrm{l}$ & 8 & Ausonia & 200 & 15 & Novo Cine & 135 & 21 \\
\hline Odescalchi & 235 & 8 & Colonna & 90 & 15 & Aurora & $\mathrm{n} / 1$ & 21 \\
\hline \multicolumn{3}{|c|}{2 to 3 changes per week } & Trieste & 140 & 15 & Faro & 100 & 22 \\
\hline Delle Vittorie & 180 & 9 & Excelsior & 165 & 15 & Impero & 115 & 23 \\
\hline La Fenice & 165 & 10 & Parioli & 180 & 15 & Preneste & 100 & 23 \\
\hline Cola di Rienzı & 190 & 11 & Sala Umberto & 105 & 15 & Edelweiss & $\mathrm{n} / 1$ & 24 \\
\hline Ambasciator & 255 & 11 & Fogliano & 115 & 16 & \multicolumn{3}{|c|}{6 to 7 changes per week } \\
\hline Astra & 180 & 11 & Vittoria & 160 & 16 & Edelweiss & $\mathrm{n} / \mathrm{l}$ & 24 \\
\hline Olimpia & 150 & 11 & Aniene & 110 & 16 & Trianon & 90 & 25 \\
\hline Brancaccio & 200 & 12 & Tuscolo & 110 & 16 & Aquila & 80 & 25 \\
\hline Golden & 200 & 12 & & & & Atlante & 120 & 25 \\
\hline Astoria & 275 & 12 & & & & Palazzo & 115 & 26 \\
\hline Bologna & 200 & 12 & & & & Corallo & 85 & 26 \\
\hline Savoia & 190 & 12 & & & & $\mathrm{ABC}$ & $\mathrm{n} / \mathrm{l}$ & 26 \\
\hline
\end{tabular}

Sources: Momento Sera; l'Unità.

Note: The admission prices are derived from Momento Sera for 1956. 
Figure1. Frequency of film turnover in 114 Roman cinemas between 2 to 29 January 1954

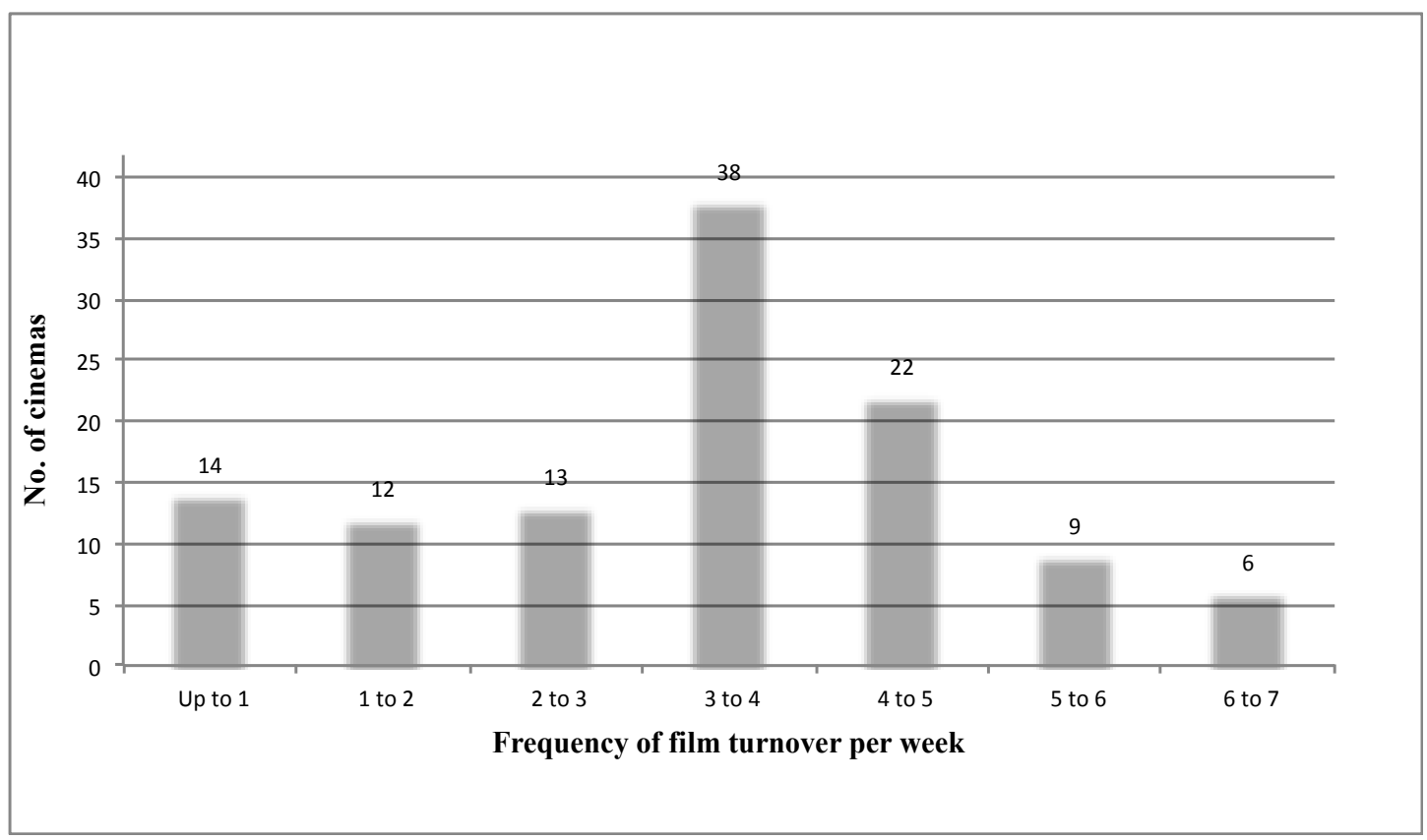

Table 6 provides further evidence of the extensive nature of the system of distribution. It lists the 20 most frequently programmed films during the 28-day period, measured by the number of screening days. Clearly, at any point in time, films that have been newly released onto the market will co-exist with films released earlier. Thus, in January 1954 three films were at the beginning of their circulation histories - Pane, amore e fantasia (1953), Vacanze romane (Roman Holiday, 1953), Storia di tre amori (The Story of Three Loves, 1953). These films were screened at a small number of (first-run) cinemas on extended runs. ${ }^{33}$ In contrast, nine of the 20 films listed were screened at 20-or-more cinemas, having been released some months earlier. Clearly, this last group, while securing plentiful bookings, which can be assumed to indicate some measure of popularity among the audiences of the lower-order cinemas at which they played, only get a small number of days bookings at each. Their day in the limelight as main attractions had passed. 
Table 6. The 20 most screened films in Rome in January 1954

\begin{tabular}{|c|c|c|c|c|c|c|}
\hline \multirow[b]{2}{*}{ Rank } & \multicolumn{6}{|c|}{ No. of screen } \\
\hline & Film & Nationality & days & No. of cinemas & Star 1 & Star 2 \\
\hline 1 & Il prigioniero di Zenda & US & 88 & 21 & Granger, $\mathrm{S}$ & Kerr, D. \\
\hline 2 & Il sergente Bum & US & 68 & 24 & Lancaster, B & Mayo, V \\
\hline 3 & Villa Borghese & Italy & 63 & 18 & Ferrero, A & De Filippo, E \\
\hline 4 & Gli avventurieri di Plymouth & US & 60 & 24 & Tracy, S & Tierney, G \\
\hline 5 & La vergine sotto il tetto & US & 57 & 23 & Holden, W & Niven, D \\
\hline 7 & Il bruto e la bella & US & 56 & 21 & Douglas, $\mathrm{K}$ & Turner, L \\
\hline 6 & Frine, cortigiana d'Oriente & Italy & 55 & 19 & Kleus, E & Cressiox, $\mathrm{P}$ \\
\hline 8 & Storia di tre amori & US & 54 & 5 & Pierangeli, A M & Douglas, $\mathrm{K}$ \\
\hline 9 & La legione del Sahara & US & 52 & 17 & Ladd, A & \\
\hline 10 & Operazione 'Z' & US & 52 & 22 & Blyth A & $\begin{array}{l}\text { Mitchum R. } \\
\text { Lamoureux }\end{array}$ \\
\hline 11 & L'incantevole nemica & Italy & 51 & 23 & Pampanini S & $\mathrm{R}$. \\
\hline 12 & Un marito per Anna Zaccheo & Italy & 48 & 16 & Pampanini, $\mathrm{S}$ & Girotti, M \\
\hline 13 & La sposa sognata & US & 46 & 23 & Grant, C & Kerr, D \\
\hline 14 & Gli sparvieri dello stretto & US & 44 & 20 & De Carlo, Y & Hudson, $\mathrm{R}$ \\
\hline 15 & E Napoli canta & Italy & 42 & 22 & Rondinella G & \\
\hline 16 & Aida & Italy & 41 & 19 & Loren, $\mathrm{S}$ & \\
\hline 17 & Pane, amore e fantasia & Italy & 41 & 2 & Lollobridgida, G & De Sica, V \\
\hline 18 & Vacanze romane & US & 39 & 3 & Peck, G & Hepburn, A \\
\hline 19 & La cieca di Sorrento & Italy & 36 & 17 & Lualdi, A & \\
\hline 20 & Tempeste sul Congo & US & 36 & 15 & Hayward, S & Mitchum, R \\
\hline
\end{tabular}

Source: l'Unità

Table 6 should not be regarded as a popularity chart. For this it is possible to turn to the trade journal Bollettino dello Spettacolo, which published tables of box-office performance for many of the cities listed in Table 2, drawn from first-run cinema sources. ${ }^{34}$ Although the historical sequence of box-office records it published for Rome are incomplete, the earnings of 115 films premiered in Rome's first-run cinemas during the period leading up to, and including, January 1954 are published, the top 20 of which can be found in Table 7. 
Table 7. The most popular films screened in Rome's first-run cinemas (Incassi prime vision), September 1953 to January 1954 and the cinemas in which they premiered

\begin{tabular}{|c|c|c|c|c|c|c|c|c|c|c|c|c|c|c|}
\hline Rank & Fim & US Title & Distributor & $\begin{array}{c}\text { Box office } \\
\text { Lire (000s) } \\
\end{array}$ & Release date & Cinema & Days & Cinema & Days & Cinema & Days & Cinema & Days & Total days \\
\hline 1 & La Tunica & The Robe & Fox & 61,694 & $27 / 11 / 53$ & Capitol & 63 & & & & & & & 63 \\
\hline 2 & Pane, amore e fantasia & Bread, Love and Dreams & Titanus & 52,410 & $22 / 12 / 53$ & Barberini & 38 & Metropolitan & 24 & & & & & 62 \\
\hline 3 & Moulin Rogue & Moulin Rogue & Fox & 34,536 & $07 / 11 / 53$ & Barberini & 14 & Capranica & 11 & Europa & 11 & Metropolitan & 14 & 50 \\
\hline 4 & Quo Vardis? & Quo Vardis? & MGM & 33,155 & $30 / 10 / 53$ & Adriano & 19 & Galleria & 29 & Supercinema & 15 & & & 63 \\
\hline 5 & Il prigioniero di Zenda & Prisoner of Zenda & MGM & 32,559 & $04 / 12 / 53$ & Adriano & 7 & Capranica & 12 & Europa & 12 & Supercinema & 7 & 38 \\
\hline 6 & Il ritorno di Don Camillo & Return of Don Camillo & Dear & 32,352 & $26 / 09 / 53$ & Barberini & 14 & Capitol & 10 & Metropolitan & 14 & & & 38 \\
\hline 7 & Vacanze romane & Roman Holiday & Paramount & 29,135 & $05 / 12 / 53$ & Ariston & 24 & Fiamma & 24 & & & & & 48 \\
\hline 8 & Il cavaliere della valle solitaria & Shane & Paramount & 25,831 & $24 / 10 / 53$ & Adriano & 6 & Barberini & 6 & Imperiale & 13 & Moderno & 13 & 38 \\
\hline 9 & Salome & Salome & Ceiad & 25,672 & $12 / 11 / 53$ & Adriano & 9 & Capranica & 9 & Europa & 9 & Supercinema & 10 & 37 \\
\hline 10 & Lucrezia Borgia & $\mathrm{n} / \mathrm{l}$ & Dear & 24,704 & $12 / 12 / 53$ & Adriano & 7 & Imperiale & 14 & Moderno & 14 & & & 35 \\
\hline 11 & La Maschera di cera & House of Wax & WB & 24,227 & $30 / 10 / 53$ & Barberini & 8 & Capranica & 8 & Europa & 8 & Metropolitan & 8 & 32 \\
\hline 12 & L'avventura di Peter Pan & Peter Pan & RKO & 23,421 & $25 / 12 / 53$ & Capranica & 14 & Europa & 14 & & & & & 28 \\
\hline 13 & Anni facili & Easy Years & Paramount & 20,685 & $14 / 11 / 53$ & Ariston & 7 & Imperiale & 14 & Moderno & 14 & Supercinema & 4 & 39 \\
\hline 14 & I vitelloni & I vitelloni & Enic & 19,337 & $29 / 09 / 53$ & Capranica & 16 & Europa & 16 & & & & & 32 \\
\hline 15 & Il Principe di Scozia & Master of Ballantrae & WB & 16,764 & $23 / 12 / 53$ & Adriano & 8 & Galleria & 8 & Supercinema & 8 & & & 24 \\
\hline 16 & Canzoni, canzoni, canzoni & Cavalcade of Song & Minerva & 16,337 & $22 / 10 / 53$ & Capranica & 8 & Europa & 8 & Metropolitan & 8 & & & 24 \\
\hline 17 & Un turco napoletano & Neapolitan Turk & Lux & 15,845 & $19 / 09 / 53$ & Capranica & 10 & Europa & 10 & Metropolitan & 7 & & & 27 \\
\hline 18 & La vedova allegra & Merry Widow & MGM & 15,584 & $15 / 10 / 53$ & Capranica & 7 & Europa & 7 & Imperiale & 9 & Moderno & 9 & 32 \\
\hline 19 & L'avventuriero della Louisiana & Mississippi Gambler & Universal & 14,424 & $21 / 01 / 54$ & Adriano & 8 & Capranica & 5 & Europa & 5 & Supercinema & 8 & 26 \\
\hline 20 & Una di quelle & One of Those & Paramount & 14,234 & $08 / 10 / 53$ & Ariston & 8 & Fiamma & 8 & Imperiale & 7 & Moderno & 8 & 31 \\
\hline
\end{tabular}

Source: Bollettino dello Spettacolo, no. 190, 31 January 1954, p. 2; l’Unità 
Using this box-office information in conjunction with the on-line daily listings found in l'Unità, it has been possible to track the 115 films back to their release dates and discover the cinemas at which they were first screened. Table 7 shows that the top 20 ranking films were premiered in one or more of 12 first-run cinemas found in the upper reaches of the listings in Table 5. Of these films, La Tunica (The Robe) was the only film to premiere in a single cinema (Capitol), with Pane, amore e fantasia and Vacanze romane, (Roman Holiday), L'avventura di Peter Pan (Peter Pan, 1953) and I vitelloni (1953), opening at two cinemas respectively the Barberini, Metropolitan; Ariston, Fiamma; and the Capranica, and Europa for the last two listed films. Table 7 also shows that a number of the cinemas were used more frequently than others to screen the top 20 'hit' films, with the Capranica and Europa each aggregating 100 days, Barberini 80 days, Metropolitan 75 days, and the Capitol 73 days.

Another interesting aspect of Table 7 is the diminishing rate at which film revenues decline with rank. Extending this observation to the 115 films listed in the Bollettino dello Spettacolo, Figure 2 illustrates a pattern that conforms to a power rule, in which revenues decline precipitously at the top end of the spectrum, but then flatten out along the range. ${ }^{35}$ The pattern shown in Figure 2 is similar to that found in studies of the North American, British, and Australian markets during the mid-1930s, and the post-war North American market. ${ }^{36}$ 
Figure 2. Films in rank order by box-office

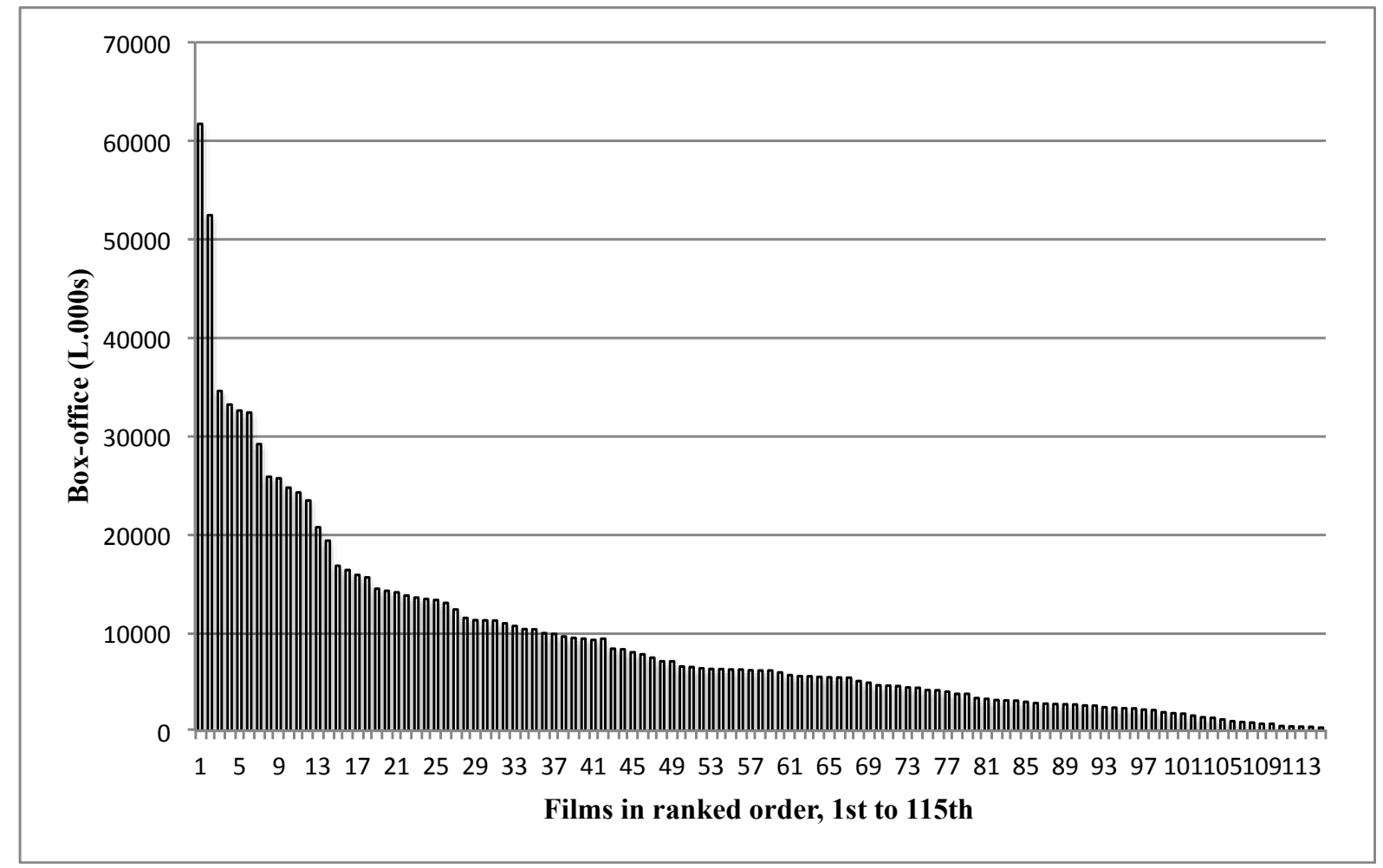

Source: Bollettino dello Spettacolo, no. 190, 31 January 1954

In keeping with Table 2, Tables 6 and 7 reveal that the top end of the Roman market was shared between American and Italian productions. In the Top 20 there are 12 Hollywood, seven Italian and one French production. With the exception of Roman Holiday and Wax Museum, the films from Hollywood are period/costume pieces; all of them, other than Roman Holiday, can be regarded as big-budget spectacles; of them, only Wax Museum is set in contemporary America; and all of them are Top 50 US productions, with six of the films taking Top 10 berths in the North American market. ${ }^{37}$ This contrasts strongly with the Italian films listed, all of which have a contemporary setting and encompass tensions of everyday living and spoken in the vernacular. (Being shot on location in Rome, Roman Holiday has 
more in common with these films.) None of the Italian films are listed as top ranking films in the US, and most do not appear to get widespread release.

The strong showing of domestically produced genres and stars indicated in Table 7 suggests that Italian films resonated strongly with Roman audiences, a finding that was confirmed in the survey, where the two most important deciding factors for going to the cinema were actors (174) and genre (155). It would appear that when established stars such as Peppino De Filippo, Sophia Loren, Gina Lollobrigida, Anna Magnani, Amedeo Nazzari, Silvana Pampanini, Vittorio De Sica, Nino Taranto, and Totò, appeared on the screen, domestic audiences were attracted in large numbers. ${ }^{38}$

\section{Audience memories of the cinema experience}

The evidence presented in the previous section about how cinema as a system of provision worked and the films that proved popular with Roman audiences, was drawn from secondary sources. What about the voice of the cinemagoers themselves? What experiential and practical information can they impart to help us understand better the decision-making, expectations and pleasure that made up the everyday experience of going to the cinema? Our findings suggest a congruency between memory and function; of how cinema was remembered in conjunction with how it operated some 50 years earlier, with each set of evidence corroborating the other.

In 1954 most of our respondents were aged between the ages of 18 and 25. For many of them, going to the cinema was an activity that was repeated regularly and for which convenience, time, opportunity and location were important determining factors. When asked which day they went to the cinema, Sunday predominated (33 per cent), followed by Saturday (14 per cent). However, a significant proportion of participants (20 per cent) recalled that they did not have a special day for attending and that they were just as likely to see films on weekdays. 
The selection of cinema venues shows those located in the neighbourhoods in which the participants lived were the most popular (mentioned by 36 per cent of participants), compared to cinemas located in the city centre (14 per cent), and those in other neighbourhoods ( 8 per cent). When respondents were asked about which type of cinema this is pattern is confirmed with only 23 per cent of maintaining they went to first-run cinemas, while 27 per cent went to cinemas in the second-run, 23 per cent to the third-run, and 27 per cent to parish cinemas. ${ }^{39}$

\section{Memories connected to the choice of cinema}

In a video diary, Giuseppina M. explains that her choice of cinema was determined by the interest she had in the film: if the film were attractive, she would go to the first run, while if she was not sure about its qualities, she would wait until it came around to the second run. For others, in the first-run you could watch films that had just come out (LAR036, LAR251): one commented, 'I knew the film was beautiful and had to watch it straight away' (LAR254). For Giuseppe V.:

Third run cinema was a 'cinema popolare', with people from the area. It was not a category of cinema for poor people, but a habit. I mean that in the first run you would go occasionally when there was a very interesting film that you really wanted to see straight away.

First run theatres are remembered as beautiful theatres (LAR009, LAR042, LAR059, LAR076, LAR080, LAR089, LAR096, LAR136, LAR176), with big blue seats (LAR009), velvet chairs (LAR058), big and very red (LAR195), with a majestic entrance (LAR243, 266), oceanic, with an upper circle, which for one respondent was an environment that transcended reality (LAR029). These cinemas were clean and welcoming (LAR036), simple (LAR047), smoky (LAR046, LAR048, LAR054), elegant (LAR078, LAR111, LAR319), 
comfortable (LAR046, LAR133), with an open roof (LAR052, LAR057), a perfect sound system (LAR090, LAR196), a perfect view of the screen (LAR168), that was also well attended (frequentato da bella gente) (LAR133). Respondents remembered velvet chairs (LAR 058), armchairs (LAR105): one spoke of the Sala Umberto with seats and cushions so comfortable 'that sometimes I used to go there to rest' (LAR159). Also mentioned was the layout of the cinema, in the shape of a shell (LAR110), and just the fact that they were clean and hygienic (LAR036, LAR186, LAR218, LAR214, LAR221, LAR305).

Describing them as beautiful and big, second-run cinemas are likewise remembered with affection by some (LAR059, LAR069, LAR082, LAR084, LAR102, LAR127, LAR158, LAR162, LAR186, LAR218, LAR279, LAR298, LAR315, LAR323); attended by elegant people (LAR068, LAR069, LAR111) - cinemas that were comfortable and well attended (LAR133). One respondent (LAR028) made the following distinction: 'The Rubino [thirdrun] had wooden chairs, while the Reale [second-run] was beautiful but you had to find a boyfriend who would take you there!'

In contrast, third run cinemas are described as both very simple, modest (LAR011, LAR152, LAR153), uncomfortable with wooden chairs and very smoky (LAR019, LAR048, LAR053, LAR054, LAR062, LAR070, LAR085, LAR087, LAR088, LAR110, LAR120, LAR129, LAR132, LAR135, LAR140, LAR146, LAR179, LAR192, LAR275). Some cinemas had a roof that could be open on a hot evening, especially to get rid of the smoke (LAR057, LAR065, LAR098, LAR120, LAR139, LAR231, LAR299, LAR303). Indeed, Giuseppina M. names Il Massimo as a cinema where during the interval the roof would open to expel the smoke. 


\section{Memories connected to the locations of cinemas}

Several interviewees confirm the wide range of cinemas available both in the centre and in the periphery. Angelo Z. remembers five theatres he could walk to in his own area, while Mirella F. mentions three and Nandy P. simply states that there were very many cinemas in her neighbourhood. For some neighbourhood cinemas were considered the place to be seen on a Saturday night. Nandy P. describes it as a destination for the stroll (lo struscio), a practice normally associated with the main street where people gathered in their best clothes to spend their time together, as well as show off to each other. This level of familiarity with the locality represents a fundamental aspect in the cinema theatre choice: looking at a local map, Giuseppina C. and Natalia M. explain that neighbourhood cinemas served as a meeting place where everybody knew each other. There were 'cinemas of your area, where people of your area would go, cinemas that no longer exist' (LAR100): one participant (LAR280) tells us that a particular cinema was just 'a room very similar to one in a house, another (LAR292) states that these cinemas were more like homes, while another (LAR296) draws parallels with her home, in that cinemas had the same wicker chairs as home, while another one describes them as big living rooms (LAR112).

In contrast to the legitimate theatre, cinemas were busy and familiar venues, where people smoked - one participant LAR181 likened them to a gas chamber - ate (Giuliana DT., LAR016, LAR098, LAR110), and chatted (LAR030, LAR110): venues where families and children would gather offering many a sense of security and wellbeing (LAR134). For one participant they were places characterised by 'lots of confusion and cheerfulness' (LAR146), corroborating Casetti and Fanchi's (2002) depiction of lower order cinemas as 'the natural extension of the road, the bar and the square', their popularity, often causing sections of the audience to watch entire films standing (LAR011, LAR039, LAR070, LAR075, LAR088, LAR103, LAR109, LAR110, LAR128, LAR129, LAR144, LAR145, LAR146, LAR168, 
LAR187, LAR191, LAR194, LAR279, LAR297). ${ }^{40}$ They were friendly and welcoming (LAR041, LAR011, LAR036, LAR040, LAR045, LAR047, LAR118, LAR154, LAR250, LAR265, LAR304); noisy (LAR062, LAR115), like a market (LAR223); but they were also a fun place to be (LAR040, LAR146), where people would make jokes while watching the film (LAR101, LAR106)

However, these qualities were not recognised by all cinemagoers: according to Carla $\mathrm{M}$. third-run cinemas were the most poorly attended, with noisy spectators and men who would often disturb women (Mirella, F., Albina), something that - according to Albina - would never happen at the Adriano, Metropolitan or Barberini (first-run cinemas). They were cinemas where you often had to watch the whole film standing, because they were so crowded (Mirella F.); where people threw cigarette ends on the floor and shouted as if they were at the stadium (Rita M.). Albina explains that there was a significant difference between educated and uneducated audiences attending cinemas in various runs, while Velia states that she was able to distinguish between a suburban and city centre audience from their clothes as well as general behaviour - city centre first-run cinemas attracted more sophisticated and elegant crowd (Maria, Rita V.). Teresa R explains the difference this way:

The popolino was always a bit shabbier. The bourgeois were easily identifiable and the difference was obvious. As one would go to cinema on a Sunday after mass, one would normally be elegantly dressed. Where you paid higher prices the difference was clear. In the third run, the audiences were more unruly and were often moving around, eating mostaccioli during the screening.

Distance and price were the recurrent themes for second and third-run cinema audiences. The cinemas they attended were close-by (LAR019, LAR021, LAR053, LAR129, LAR285, LAR286, LAR304), and affordable - much cheaper than the first-run (LAR051, LAR128, 
LAR152, LAR140, LAR146, LAR153, LAR167, LAR168, LAR187, LAR197, LAR214, LAR215, LAR217, LAR231, LAR270, LAR275, LAR283, LAR294, LAR318). ${ }^{41}$ One respondent maintained that first run cinemas were those that you could afford when you were older (LAR031).

\section{Memories connected to the experience of cinema}

Although several participants remembered the technical presentation of films as sometimes wanting, in that the film reel at times would break or the image would be out of focus (LAR063, LAR085, LAR086), this did not stop audiences feeling the cinema to be a magical place: 'a place outside of this world, magic' (LAR063), a 'fascinating place which was not part of life and while I was sitting in the cinema I felt part of the film' (LAR113); a place where 'every time I was in the cinema I was impressed by these images coming out of a big screen' (LAR097) or a 'massive cinema with a screen that captured you' (LAR138).

\section{Memories connected to the industrial organisation of cinema}

Corroborating the velocity at which film programmes changed in lower order cinemas (see Table 6), Giuseppe V. remembers:

'Third run cinemas would show a film only for a few days, not like today, as they were neighbourhood cinemas and needed to change the programming as otherwise they would run out of audiences. Also there was the story of the film reels which often had to be exchanged amongst cinemas in the neighbourhood, so while one cinema was showing the first part, the other would be showing the second. 
Giuseppe V., reminds us of the differences in patterns of film distribution between then and now: 'nowadays it is all first run, and if you miss a film after a month that has come out, you can't see it again...At the time a film would be programmed for a year, as it would move from first to second and third run'. For lower order cinemagoers waiting for a popular film to get to a neighbour hood cinema required patience. Carla M. testifies that the success of a film determined the speed at which it would move to lower runs: if it was not very popular, you could see it very quickly, however, if this was not the case then you had to wait for a long time. Giuliana DT explains a further advantage to the extended life of a movie as it was distributed over time across the different runs:

The fact that the films would stay on for a long time allowed you first of all to listen to the film review and being attracted to them, as well as the fact that you could watch them flexibly - you could be late, watch it a second time, and feel welcomed in the movie theatres.

On this point Angelo DT. remembers that once you had paid for a ticket you could stay in the cinema for the rest of the day. Maria Rita V. confirms this practice when saying that not only you could watch it at whatever time, but you could watch the same scene more than once, so you could spend the afternoon there.

Another aspect of exhibition was the tradition of showing some films at specific points in the calendar. Angelo DT remembers how La Tunica (The Robe) and Quo Vadis? - listed respectively first and fourth in Table 7 - were '...classics and that you could not pass Easter without seeing'. Their characters were the 'superheroes of those times'. Nandy P. confirms this by explaining that this strategy allowed people who had not yet seen them to watch them for the first time, while those who had seen them before could see them again. 
In addition to those cinemas classified as first, second and third-run, was another set comprising half-a-dozen or so cinemas that were collectively known as Cinema Varietà combining both stage acts with film screenings. These cinemas tended to have multiple change film programmes during the week, screening films after they had been through both first and second-run cinemas. Listed in Table 5, the cinemas Alhambra, Ambra Jovinelli, Aurora, La Fenice, Il Principe, and Volturno all served as Cinema Varietà. For Giuseppe V. this was a strategy adopted by some exhibitors 'in order to attract larger audiences'. Angelo DT, in fact, remembers how at the Alambra he saw Totò performing on stage. Rita M. remembers Totò, as well as Nino Taranto appearing at Il Principe, where her mother would take her with friends in the afternoon. Mirella F. also remembers seeing Totò, and on separate occasions Anna Magnani, and Alberto Rabbagliati at the cinema Appio (listed by Il Tempo as second-run); while Anna N. assures us that the variety show at the Fenice and Volturno was not really outrageous, as it only presented a few 'legs moving across the stage'.

Interestingly, with threat posed by the arrival of television, some exhibitors took action to ensure that the new medium did not steal audiences from them. ${ }^{42}$ For instance, Natalia M., remembers how those people who could not afford television, would go to the cinema on Thursday evenings - the Tuscolo cinema did this - when the highly popular TV quiz show Lascia e Raddoppia (Double or Nothing) was scheduled for broadcast, causing the main feature to be interrupted in order for the TV programme to be shown. This interesting artefact ties in with the earlier discussion around Table 7 concerning the films being made by Italian producers about everyday life.

Finally, a participant (Mirella F.) remarked on her experience of working at the Roman offices of the distribution arm of $20^{\text {th }}$ Century Fox, drawing attention to strong links between audiences and industry that prevailed in the city. In one revealing passage in her interview she tells of how her employer required local employees to generate word-of-mouth. 
There was a small projection room near the office and before a film was premiered, all employees had to watch it and were asked to publicise it, to say that the film was beautiful and that we had already seen it. So we were the ones who would start the marketing process. And we were happy to do it because - apart from a good salary - we received a bonus when a film came out, it could be a 14 th or the $15^{\text {th }}$ annual salary according to which film was premiered. We would publicise the film and watching it earlier than everybody else we would get excited about it!'

\section{Discussion and conclusion}

This work incorporates two mutually reinforcing methodologies with the purpose of producing a bottom-up account of cinemagoing as a social activity. The oral history component recounts the memories of elderly Romans, who were active cinemagoers in the 1950s. These memories are emotional, experiential and practical in nature comprising recollections of location, space, design, comfort, noise, smell, crowds, proximity, intimacy, food, movement, light, and darkness, often occasioned by important personal events such as first dating. Going to the cinema for our participants took the form of repeated rituals that became part of their 'shared histories': a process that Mariagrazia Fanchi has termed the 'space of vision' (spazio di visione).$^{43}$ Their memories reflect Martin Barker's concern about 'What spaces and traditions are available to people and how ...these shape and enable participation. ${ }^{44}$ If, as Laura Marks recounts, '... sense memories are most fragile to transport, yet most evocative when they can be recovered', the testimonies offered by our participants help us draw a rounder depiction of what going to the cinema meant for their contemporaries. $^{45}$

Drawing upon newspaper programme listings and supported by secondary data produced by industry-wide bodies, a second methodology cloaks the reported experiences of our participants in a framework of industrial provision. From the evidence presented in Tables 6 
and 7 and Figure 2, it is clear that audiences made choices between films, the consequence of which was that those films that proved more popular were given greater distribution. From this type of evidence it is difficult to get away from the idea that films were important to audiences in their own right. Yet, problematically, in the interviews, questionnaires and diaries, our elderly Roman participants rarely mention the films that they went to see. For instance, Renata I. is frustrated when she admits to not remembering what films she saw during the period, while she remembered the cinemas she attended. Carla M. is similarly disappointed, and although Teresa R. states that '... we used to go to the cinemas and choose the films', in her diary entry the cinemas are recounted while the films are not. Such evidence supports Richard Maltby's claim that '...the primary relationship with the 'cinema' has not been with individual movies-as-artefacts or as texts, but with the social experience of cinema', a view in keeping with Robert Allen's conception of performance based on the '...immediate social, sensory, performative context of reception' and Christine Geraghty assertion that '...gazing at the screen was only one of a number of things which could be done in the cinema' ${ }^{46}$ Here, Roland Barthes' (1987) well-known distinction between what he terms a 'narcissistic body' and a 'perverse body' is fitting. ${ }^{47}$

Our elderly Romans remember strongly the noise and smells of going to the cinema (the noise from the auditorium, where 'people would make jokes while watching the film', turning the cinema into a market or a stadium); the boundaries of space (first, second and third run cinemas, lower and upper circles, the closeness of obscure bodies); the darkness of the theatre; and the ebb and flow of audiences coming and going.

Is it the nature of memory that provides the key to understanding the conundrum that films seem to matter at least to a section of the audience but are not much remembered? Here Katherine Nelson's distinction between generic event memory (such as going to the cinema) 
that provides general outlines of a familiar event, without specific information of the event itself (whether it is the date, the time or the title of a film), and episodic memory, which is triggered when it is part of a personal history, is perhaps pertinent. ${ }^{48}$ For instance, in her video diary Carla remembers watching Walt Disney's Fantasia (1940) because it was the first and only time she went to the cinema with her mother. She remembers it as a special occasion and she refers to parts of the film that stuck in her mind. However, for the most part cinemagoing was a repetitious activity and, in general, the films seen were not sufficiently strong to stand out.

In developing this research the authors are mindful of Alessandro Portelli's stricture that '... oral history is about the historical significance of personal experience on the one hand, and the personal impact of historical matters on the other'. ${ }^{49}$ In allowing film audiences to speak for themselves '...through the labour of memory and the filter of language', it has been possible to sense their particular collective experience of going to the cinema in 1950s Rome, while at the same time giving form to the institutional arrangements that made that experience possible and evidence of the films that were particularly attractive to audiences at the time. ${ }^{50}$ The mixed methods approach adopted here has allowed what Nigel Fielding has termed 'convergent validation' to take place, making the findings derived from each method deeper than would have been the case had a mono-method approach been followed. ${ }^{51}$ The fact that box-office and film programming data lend themselves to a narrative about choice and preferences appears to be at odds with what is remembered suggests that as a general rule the specific 'narcissistic' experience of seeing films may be transient. ${ }^{52}$ Nevertheless, ultimately, films were why people went to the cinema. This shouldn't be lost sight of.

Finally, this case study about the film business and audiences of Rome, is part of a broader mixed methods project that studies the experiences of audiences and the business structures 
that supplied them with films throughout the Italian peninsular, during the 1950s.

Investigating distributive circuits and exhibitor chains by means of the films released and their exhibition histories is still an underdeveloped area of study, revealing as it does a great deal about the international alliances formed between Hollywood distributors and local groupings of exhibitors in competition with indigenous producers, distributors and exhibitors: an essential backdrop for understanding the different aspects of film reception. Putting the film, at the centre of a study in which complex industrial practices and box-office outcomes, are contextualised by the experiences of filmgoers, is at the heart of this national study.

\section{Notes}

${ }^{1}$ This share was similar to that absorbed by cinema in the American and British markets at this time. See H.E. Browning and A.A. Sorrell, "Cinema and cinema-going in Great Britain," Journal of the Royal Statistical Society, 117 (1954): 133-165, John Sedgwick, "Product Differentiation at the Movies: Hollywood, 1946-65," Journal of Economic History, (2002): 62 (2002): 676-704.

2 Elena Mosconi, "L'offerta, il consumo e la produzione di cinema nell'Italia anni Cinquanta," Comunicazioni sociali, Year XVII, n. 2-3 (April-September 1995), 332.

${ }^{3}$ Browning and Sorrell, "Cinema and cinema-going in Great Britain" derive their data from a report published by UNESCO (1952) Basic Facts and Figures. Also see Vent'anni di Anica per il cinema italiano, 1944-1964, (Rome: Anica, 1965).

${ }^{4}$ See for instance Tony Judt, Postwar: A History of Europe since 1945 (London: Pimlico, 2007): 231-35; Richard Pells, Not Like Us. How Europeans Have Loved, Hated, and Transformed American Culture Since World War II (New York: Basic Books, 1997); Richard Pells, "American Culture Abroad. The European Experience since 1945," in American Mass Culture in Europe, ed. R. Kroes, R.W. Rydell, and D.F.J. Bosscher (Amsterdam: VU University Press, 1993), 67-83; Giuliana Muscio, "Invasion and Counterattack," in 'Here, There and Everywhere'. The Foreign Politics of American Popular Culture, ed. R. Wagnleitner, and E. Tayler May (Hanover, NH: University Press of New England, 2000), 116-131.

${ }^{5}$ See Daniela Treveri Gennari, "A Regional Charm: Italian Comedy versus Hollywood," October (Spring 2009, No. 128: 51-68).

${ }^{6}$ Barbara Corsi, Con qualche dollaro in meno. Storia economica del cinema italiano (Rome: Editori Riuniti, 2001), 107; Barbara Corsi, "Il pubblico, un gigante sconosciuto," in Storia del cinema italiano, Vol. IX - 1954-1959, 442-450 (Venice: Marsilio Editori, 2004), 445.

${ }^{7}$ The survey of and interviews with elderly Romans was made possible by a British Academy Mid-Career Fellowship awarded to Daniela Treveri Gennari in 2011. 
${ }^{8}$ Martin Barker and Ernest Mathijs (eds.), Watching Lord of the Rings: Tolkien's World Audiences (New York: Peter Lang, 2008); Daniel Biltereyst, Kathleen Lotze, and Philippe Meers, "Triangulation in historical audience research: Reflections and experiences from a multi-methodological research project on cinema audiences in Flanders.”Particip@tions, Volume 9, Issue 2 (November 2012), pp. 690-715.

${ }^{9}$ Evidence presented in Table 3 suggests that the major cities in Italy had similarly developed distribution and exhibition systems.

${ }^{10}$ This finding also differs from that that proffered by Paola Valentini, La scena rubata. Il cinema italiano e lo spettacolo popolare (1924-1954) (Milan: Vita e Pensiero, 2002), 114. On 'mercato di profondità' see Alessandro Ferraù, "Rapporto tra gli incassi delle prime visioni di 16 città capozona e il resto del mercato nazionale," Cinespettacolo, 1-2, (1-30 Jan 1956).

${ }^{11}$ Annette Kuhn, An Everyday Magic: Cinema and Cultural Memory (London: I.B. Tauris, 2002), 35 .

${ }^{12}$ Douglass North, Institutions, Institutional Change and Economic Performance, (Cambridge, Cambridge University Press, 1990). For a discussion on this see J. Sedgwick, , C. Pafort-Overduin, and J. Boter, , "Explanations for the restrained development of the Dutch cinema market in the 1930s," Enterprise and Society, 13, 3 (2012) pp. 634-671.

${ }^{13}$ Jurca and Sedgwick, Film History (forthcoming) found that during the 1930s Philadelphia audiences attending 3rd and 4th run cinemas had their favourites every bit as much as those attending first-run houses.

${ }^{14}$ For detailed historical analysis based upon film programmes see John Sedgwick and Michael Pokorny, "The film business in the U.S. and Britain during the 1930s", Economic History Review, 58, (2005): 79-112; John Sedgwick, Clara Pafort-Overduin, and Jaap Boter, "Explanations for the restrained development of the Dutch cinema market in the 1930s," Enterprise and Society, 13, 3 (2012): 634-671; John Sedgwick, Michael Pokorny and Peter Miskell, "Hollywood in the world market - evidence from Australia in the mid-1930s," Business History, 56, n.5, (2014) 689-723.

${ }^{15}$ Questionnaires were given out and collected by the Principal Investigator (PI) of the research project and by a Research Assistant (RA).

${ }^{16}$ http://archivio.unita.it/

${ }_{17}$ The trade journal exhibitors' organisation AGIS produced a bi-weekly publication Bollettino dello Spettacolo in which box-office returns of first-run cinemas in the largest Italian cities were published. The entries for Rome were sporadic. The 28 days 2-29 January were selected because they were included in the most comprehensive listing of Roman cinemas to appear in the journal in 1953 and 1954, making it possible to cross reference the frequency of screenings in Rome and the box-office returns of the films screened.

${ }^{18}$ Barbara Corsi, Con qualche dollaro in meno. Storia economica del cinema italiano, 117118; 'There are several films which in first run cinemas become very successful and also there are several films which - thanks to the success obtained in first run cinemas - are able to find a mercato di profondità' linked to the box-office profit of first run cinemas' (Alessandro Ferraù, "Un anno di “prime visioni”", Borsa Film, n. 41, 1 st Aug 1959).

${ }^{19}$ Alessandro Ferraù, "Rapporto tra gli incassi delle prime visioni di 16 città capozona e il resto del mercato nazionale," Cinespettacolo, 1-2, (1-30 Jan 1956).

${ }^{20}$ Peter Miskell and Marina Nicoli (unpublished monograph).

${ }^{21}$ Daniela Treveri Gennari, Post-War Italian Cinema: American Intervention, Vatican Interests (New York: Routledge, 2009). In 1954 there are around 4000 parish cinemas in Italy, 1875 of them are able to screen feature length films (Mariagrazia Fanchi, "Non censurare ma educare! L'esercizio cinematografico cattolico e il suo progetto culturale e 
sociale." In Attraverso lo schermo. Cinema e cultura cattolica in Italia, ed. R. Eugeni, D. Viganò, Rome: Ente dello Spettacolo, 2006, 106).

${ }^{22}$ Ruth Vasey, The World according to Hollywood, 1918-1939 (Exeter University Press: Exeter, 1997), 92

${ }^{23}$ On widescreen display of films see J. Belton, Widescreen Cinema (Cambridge, MA: Harvard University Press, 1992). For the attraction of this format in Italy, see Federico Vitella, "Una questione di standard. Il passaggio dall'Academy ai formati panoramici." In Federico Vitella and Luca Mazzei (eds.), Geometrie dello sguardo. Contributi allo studio dei formati nel cinema italiano (Roma: Carocci, 2007), 65-130, 78-81.

${ }^{24}$ M. Siniscalco, "Settecento milioni di spettatori." Rassegna del Film, Vol. I, n. 8 (Nov. 1952), 26; See also Mariagrazia Fanchi 'Non censurare ma educare! L'esercizio cinematografico cattolico e il suo progetto culturale e sociale," 107.

${ }^{25}$ Annuario dello Spettacolo, 1957, Table 45.

${ }^{26}$ Annuario dello Spettacolo, 1957, Table 56.

${ }^{27}$ How this figure is arrived at is not explained and may well include approximately 30 openair cinemas (mainly operating during the summer months) and over 50 parish cinemas.

${ }^{28}$ Daniela Treveri Gennari, "'If you have seen it, you cannot forget!": Film consumption and memories of cinema-going in 1950s Rome," The Historical Journal of Film Radio and Television, Vol. 35, Issue 1, (Feb. 2015) pp. 53-74.

${ }^{29}$ The Bollettino dello Spettacolo lists the earnings of films in each of the three runs for Rome and Milan. Box-office in other cities is restricted to first-run. A better source of information on this subject is to be found in the city editions of national newspapers and, of course, local newspapers.

${ }^{30}$ Annuario dello Spettacolo 1957, Table 26.

31 Those cinemas that have incomplete exhibition records or are closed for more than two days during January 1954 have been excluded from the analysis.

${ }^{32}$ Effective, but not necessarily sophisticated. Later in the paper one diarist (Giuseppe V.) recalls reels of films being transported from one cinema to another during the course of a screening.

${ }^{33}$ The most popular film screened in Rome La tunica (The Robe), released in December 1953, does not get into the Table 6 because it was screened at just one cinema, amassing only 28 playing days.

${ }^{34}$ Milan is an exception, with listings drawn from first, second and third-run cinemas.

${ }^{35}$ A. De Vany, and W. Walls, "Bose-Einstein Dynamics and Adaptive Contracting in the Motion Picture Industry,” Economic Journal 106 (1996): 1493-1514.

${ }^{36}$ Respectively, Sedgwick, and Pokorny, "Product Differentiation at the Movies: Hollywood, 1946-65;" John Sedgwick, Michael Pokorny and Peter Miskell, "Hollywood in the world market - evidence from Australia in the mid-1930s;" Sedgwick, "Product Differentiation at the Movies: Hollywood, 1946-65."

${ }^{37}$ Top ranking films in the US are obtained from Variety's annual presentation of Top Grossing Films, found in one of the January editions of the trade journal - see Sedgwick, "Product Differentiation at the Movies: Hollywood, 1946-65."

${ }^{38}$ See the discussion in Federico Villa, "Consumo cinematografico e identità italiana," in Mariagrazia Fanchi and Elena Mosconi (eds.) Spettatori. Forme di consume e pubblici del cinema in Italia 1930-1960 (Rome - Venice: Bianco \& Nero - Marsilio, 2002), pp. 189-203, 194-197.

${ }^{39}$ These numbers sum to more than 325 because respondents were given more than one choice. For an account of social class and the type of cinema audiences attended see Barbara 
Corsi, "Il pubblico, un gigante sconosciuto," in Storia del cinema italiano, vol. IX, 19541959 ed. Sandro Bernardi (Venice: Marsilio editori, 2004) 442-450, 446.

${ }^{40}$ Francesco Casetti and Mariagrazia Fanchi, "Le funzioni sociali del cinema e dei media: dati statistici, ricerche sull'audience e storia del consumo," in Mariagrazia Fanchi and Elena Mosconi (eds.) Spettatori. Forme di consume e pubblici del cinema in Italia 1930-1960 (Rome - Venice: Bianco \& Nero - Marsilio, 2002), pp. 135-171, 154.

${ }^{41}$ On the subject of cinemas within walking distance from home see Annette Kuhn, $A n$ Everyday Magic: Cinema and Cultural Memory, 34.

${ }^{42}$ Paola Valentini , La scena rubata. Il cinema italiano e lo spettacolo popolare (1924-1954) (Milan: Vita e Pensiero, 2002), 96.

${ }^{43}$ Katherine Nelson, "The Psychological and Social Origin of Autobiographical Memory." Psychological Science. Vol. 4 n. 1 (Jan 1993), 13; Mariagrazia Fanchi, Spettatore (Milano: Editrice Il Castoro, 2005), 17.

${ }^{44}$ Martin Barker, "Crossing Out the Audiences," in Audiences: Defining and Researching Screen Entertainment Reception, ed. Ian Christie (Amsterdam: Amsterdam University Press, 2012), 190.

${ }^{45}$ Laura Marks, The Skin of the Film: Intercultural Cinema, Embodiment, and the Senses. (Durham, NC: Duke University Press, 2000), 111.

${ }^{46}$ Richard Maltby, "On the prospect of writing cinema history from below," Tijdschrift Voor Mediageschiedenis. 9 (2) (2006), 85; Robert Allen, "From exhibition to reception: reflections on the audience in film history," Screen, 31:4 (1990), 352; Christine Geraghty, "Cinema as a Social Space: Understanding Cinema- Going in Britain, 1947-63," Framework. The Journal of Cinema and Media (2000). (http://www.frameworkonline.com/Issue42/42cg.html, accessed on $26^{\text {th }}$ November 2013)

${ }^{47}$ Roland Barthes, The Rustle of Language (New York: Farrar, Straus \& Giroux, 1987), 349.

${ }^{48}$ Katherine Nelson, "The Psychological and Social Origin of Autobiographical Memory." Psychological Science. Vol.4 n. 1 (Jan 1993), 7.

49 Alessandro Portelli, "A dialogical relationship. An approach to oral history," http://www.swaraj.org/shikshantar/expressions_portelli.pdf, accessed 23 ${ }^{\text {rd }}$ October 2013

${ }^{50}$ Portelli, "A dialogical relationship. An approach to oral history."

${ }^{51}$ Nigel Fielding, "Triangulation and mixed methods designs: Data integration with new research technologies." Journal of Mixed Methods Research 6, no. 2 (2012), 127.

${ }^{52}$ F. J. Shih, "Triangulation in nursing research." Journal of Advanced Nursing, 28 (1998), 633. 